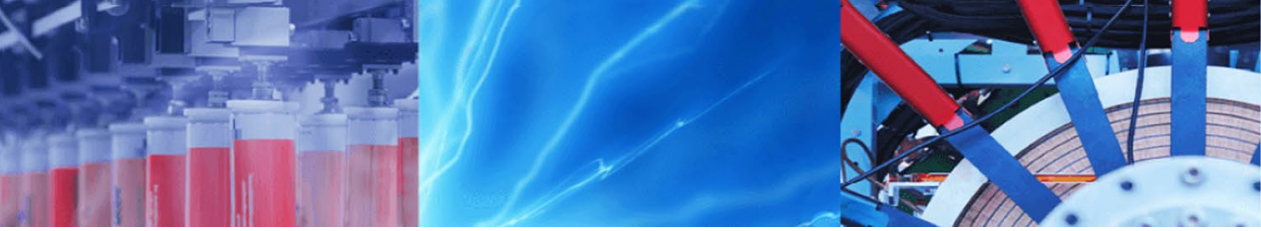

Research Article

\title{
Remediation of COD and color from textile wastewater using dual stage electrocoagulation process
}

\author{
G. K. Singh ${ }^{1} \cdot$ N. B. Singh ${ }^{1,2} \cdot$ S. P. Shukla ${ }^{1,3} \cdot$ Markandeya $^{4}(\mathbb{D}$ \\ (c) Springer Nature Switzerland AG 2019
}

\begin{abstract}
The study has been done to investigate the effects of the current density on COD removal, color removal and electrode consumption on simulated textile wastewater using malachite green dye in the dual stage electrocoagulation process with settler. The results indicated that double stage electrocoagulation with settler is efficient at current density $165 \mathrm{~A} / \mathrm{m}^{2}$ and able to attain $92.60 \%$ COD removal and over $93.11 \%$ color removal. The most suitable current density for process is $135 \mathrm{~A} / \mathrm{m}^{2}$ in term of COD and color removal efficiency giving removal of 90.93 and $92.18 \%$, respectively. analysis of variance (ANOVA) reveals that COD removal consistently changes for different COD concentrations among first and second stage electrocoagulation as well as settler. However, Tukey's test shows significant $(P<0.001)$ removal of COD. In case of color, ANOVA reveals significantly different color concentration among first and second stage electrocoagulation as well as settler. Moreover, Tukey's test also shows significant $(P<0.001)$ removal of color. In case of electrode consumption, $t$ test revealed significant electrode consumption. Correlating the removal of COD concentration $(\mathrm{mg} / \mathrm{L})$ and electrode weight loss $(\mathrm{mg})$ by Pearson correlation analysis for 1 st reactor and 2 nd reactor, it revealed a significant and positive correlation between COD removal and electrode weight loss $(r=0.98, P<0.001)$ indicating that as removal in COD concentration increases, electrode weight loss increases.
\end{abstract}

Keywords Electrocoagulation $\cdot$ COD $\cdot$ Color $\cdot$ Current density $\cdot$ Wastewater

\section{Introduction}

Water is one of the most essential components for the life of living beings on earth. Among many water consuming industries; textile is the one which releases wastewater having high concentrations of $B O D, C O D$, heavy metals, $\mathrm{pH}$ and toxic colored compounds etc. into the ecosystem, which causes one of the most remarkable sources of visual pollution and perturbation in the aquatic life as well as public health $[14,20]$. The color and polluting agent not only lead to undesired water properties but also disturb the light transmission, photosynthesis under water and thus water body $[17,19]$. Therefore, it is essential to treat textile industry effluent in feasible, viable and economical manner.

Many technologies like adsorption, coagulation-flocculation and membrane based technologies, biological methods, advanced oxidation/reduction methods etc. [5, $11,12]$ have been reported to treat textile industry effluents. Adsorption onto activated carbon is associated with high cost, difficult regeneration and high waste disposal cost while other current processes are not economically feasible on a large scale [16, 18, 28]. Recently, due to addition of electrochemical process to these technologies, the removal of organic pollutants especially organic dyes from various effluents are common [10, 21]. Electrochemical techniques were traditionally used for synthesis

\footnotetext{
$\triangle$ Markandeya, mktiwariiet@gmail.com; markandeya.civ@iitbhu.ac.in| ${ }^{1}$ Department of Civil Engineering, Institute of Engineering and Technology, Lucknow 226021, India. ${ }^{2}$ Harcourt Butler Technical University, Kanpur 208002, India. ${ }^{3}$ Rajkiya Engineering College, Banda 210201, India. ${ }^{4}$ Department of Civil Engineering, Indian Institute of Technology (BHU), Varanasi 221005, India.
} 
of various compounds or for metal recovery but in recent times, other processes have been come into existence including their significant role in different textile industries processes. Oxidative processes have been reported to be effective in chemical degradation such as chlorine, but it produces some very toxic products such as organic chlorine compounds $[23,25]$. Advanced oxidation processes such as ozonation, ultra-violet (UV) and ozone-UV combined oxidation, photo catalysis, Fenton reactive and ultrasonic oxidation are not economically feasible $[4,27$, 32]. Electrocoagulation and electro coagulation/flotation processes can be applied to a wide range of both water and wastewater treatment projects and is most effective in removing inorganic contaminants and pathogens. Because of their wide use, they have been used for groundwater and surface water remediation at several sites [33]. These processes are characterized by ease of operation, reduced production of sludge and negligible consumption of chemicals. They have been applied efficiently to various water treatment problems. So, if electrocoagulation could replace normal chemical coagulation processes, very little alteration would be required to make the present treatment plants more efficient and resolve those many troubles caused by chemical coagulation [15].

In recent years, some of the researchers have found that electrocoagulation showed better removal efficiency in COD, color, turbidity and total dissolved solids $[2,3]$ in dye laden wastewater discharged from textile industries. Electrocoagulation process provides a simple process for the treatment of wastewater without any need of supplementary chemicals, due to which no secondary pollution occurs. It also minimizes the rate of sludge production, which has to be disposed. In most basic terms, electrocoagulation is a process in which electrical current is applied on wastewater for in situ production of coagulant through electrolytic oxidation of a suitable anode material [6]. This coagulant then forms large agglomerates with the various cation species in the impurities in wastewater and either settle to bottom or rise up on the top along with the gases produced [1,29]. A major advantage of electrocoagulation above commercial techniques is that dosage of the coagulant can be controlled by adjusting the current which makes process of wastewater treatment very easy $[7,8,22,30,35]$.

The present study will be carried out to investigate the following: (1) applicability of the electrocoagulation procedure for the treatment of synthetic textile wastewater prepared using malachite oxalate green dye in laboratory. (2) The effects of current density on COD removal, color removal, Electrode consumption for the unit COD removal and to study the effect of combination of reactors with settler.

\section{Materials and methods}

\subsection{Preparation of synthetic textile wastewater}

\subsubsection{Malachite green dye}

Wastewater discharged from various processes from different coloring industries including textile are usually polluted by dyes. Malachite green is one of the most commonly used dye. It is mostly used for the dyeing of cotton, silk, paper, leather and also in manufacturing of paints and printing inks, are toxic and must be removed before discharge into water bodies. About $10-15 \%$ of all dyes are combined to wastewater in the dyeing process [26].

Malachite green oxalate dye, C.I. Basic Green 4, Classification Number 42,000, chemical formula $=\mathrm{C}_{52} \mathrm{H}_{54} \mathrm{~N}_{4} \mathrm{O}_{12}$, molecular weight $=463.50, \lambda \max =618 \mathrm{~nm}$ (measured value) was supplied by Sigma-Aldrich (M) Mumbai, India (Fig. 1).

Synthetic textile wastewater having dye concentration $300 \mathrm{mg} / \mathrm{L}$ was used in our experimental work. The dye was then accompanied with the following chemicals (sodium chloride $0.3 \mathrm{~g} / \mathrm{L}$, hydrolyzed starch $3 \mathrm{~g} / \mathrm{L}$, ammonium sulphate $0.0174 \mathrm{~g} / \mathrm{L}$, disodium hydrogen phosphate $0.0174 \mathrm{~g} / \mathrm{L}$ and detergent drops in order to correctly simulate the actual dye waste released from textile industries (all the chemicals and reagents used were purchased from SD fine chem. Ltd. Mumbai). This mixture was then added
Fig. 1 Chemical structure of malachite basic green-4 dye

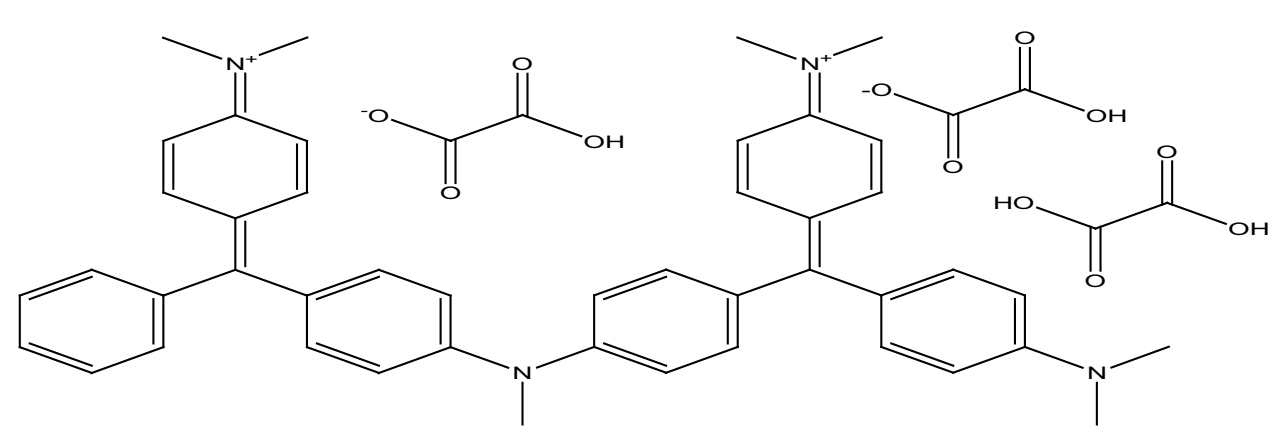


to the distilled water and heated at $100^{\circ} \mathrm{C}$ for $30 \mathrm{~min}$ and cooled to room temperature.

\subsection{Reactor design}

The experimental system included two EC reactor made up of acrylic sheet. The total volume of both reactors was 5.4 and had $3 \mathrm{~L}$ of working volume each. A cassette was also organized so that electrodes were held at their individual positions during the experiment. The dimensions of each Al electrode used were $9.7 \times 8.0 \times 0.2 \mathrm{~cm}$ making their effective surface area as $160 \mathrm{~cm}^{2}$. The two anodes and three cathodes were set in a monopolar configuration. The overall effective surface area of electrodes in reactor was $800 \mathrm{~cm}^{2}$. Inter electrode spacing was kept at $2 \mathrm{~cm}$ and reactors were connected to a DC power supply unit in series mode. The ammeter and voltmeter installed in power supply helped in recording electric current and voltage values. Two reactors were followed by a settler prepared by acrylic sheet. Settler consisted of 22 parallel plates with each plate inclined at an angle of $60^{\circ}$ to the horizontal making total working volume of $7.4 \mathrm{~L}$. Parallel plates were of acrylic sheet and having total effective surface area of $5200 \mathrm{~cm}^{2}$ to provide improved settling. Flow rate was kept at $200 \mathrm{~mL} / \mathrm{min}$ for all the experimental runs. HRT was $37 \mathrm{~min}$ for settler and $27 \mathrm{~min}$ for both the reactors.

\subsection{Experimental procedure}

Wastewater was flowed into the first reactor from an over head tank through plastic pipe ending up in a ball valve adjusted with pump at required flow rate. The experimental runs at the rate of $200 \mathrm{~mL} / \mathrm{min}$ were performed continuously in double stage reactor system which was followed by settler. The $\mathrm{pH}$ was kept between 5 and 7 in this study.

The runtime of each experimental run was considered to start when DC power supply unit was switched on. Anodes were consumed during the course of the run while hydrogen gas was evolved at the cathode helping the scum material to float at the top. After the steady state was achieved, $10 \mathrm{~mL}$ samples were withdrawn from both the reactors and settler after every $20 \mathrm{~min}$. Samples were then analyzed for COD and color removal. Current and voltage were noted down at the time of sample collection for the calculations. The consumption of electrodes was weighted before and after the completion of run.

After each experimental run, electrodes were washed thoroughly and then mechanically scraped so that their clean surface was exposed for the next run. Reactors and settler were also washed cleanly after each run, so that any scum particles were removed. Figure 2 shows the experimental setup.

\subsection{Evaluation of removal efficiency}

\subsubsection{Analytical study}

Standard method was used for the analysis of tested physico chemical parameters as described in standard methods for the examination of water and wastewater analyses [31]. Each sample taken from the electrocoagulation cell was analyzed in the laboratory.

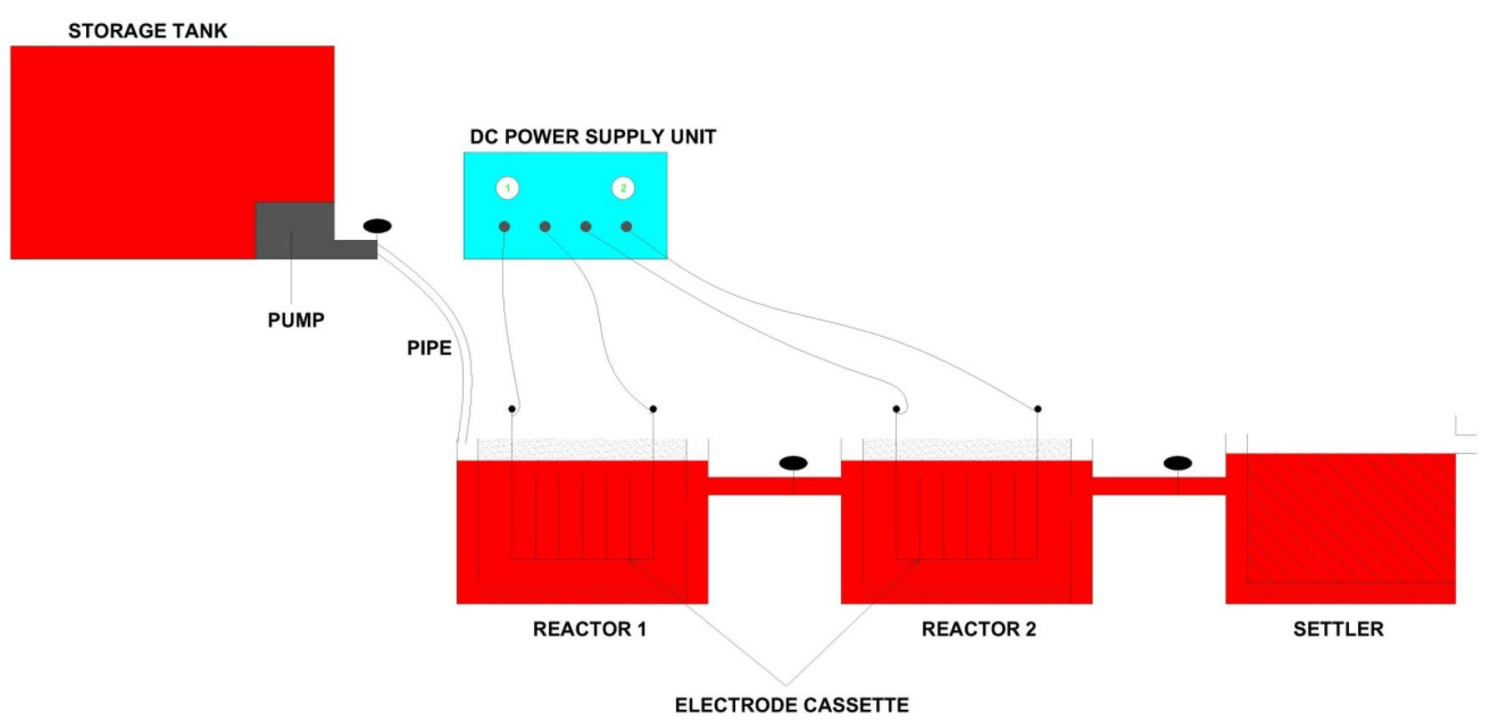

Fig. 2 Experimental setup electrocoagulation process 
2.4.1.1 COD The removal efficiency of COD in synthetically polluted water treated by electrocoagulation was calculated as follows:

$Y \%=\frac{C_{0}-C}{C_{0}} \times 100$

where; $Y \%$ is the COD removal efficiency, $C_{0}$ is the COD concentration at initial $(\mathrm{mg} / \mathrm{L}), \mathrm{C}$ is the COD concentration at any time (mg/L).

COD was determined using the COD analyzer (AQUA LYTIC model no. PCH 70361).

2.4.1.2 Color Efficiency of color removal was expressed as percentage of absorbance removal calculated as:

Percentage color removal $=\frac{C_{i}-C_{f}}{C_{i}} \times 100$

where; $C_{i}$ is the initial concentration of color in wastewater (at $618 \mathrm{~nm}$ ), $C_{\mathrm{f}}$ is the final concentration of color in treated wastewater.

Color was determined using UV-VIS spectrophotometer (Chemito instruments Pvt. Ltd. Model UV 2000).

\subsubsection{Statistical analysis}

Data was summarized as mean \pm SD. Pre and post groups were compared by paired $t$ test. Groups were also compared by one way analysis of variance; ANOVA followed by Tukey's multiple comparison test. Pearson correlation analysis was done to assess association between removal of COD concentration and electrode consumption (weight loss). A 2-tailed $P$ value less than 0.05 was considered statistically significant. PRISM version 5.0 statistical software was used for the analysis of data.

\section{Result and discussions}

\subsection{Effect of current density on the removal of COD}

The experiments were carried out to understand the effect of electrocoagulation process when current density was varied from 30 to $165 \mathrm{~A} / \mathrm{m}^{2}$ in difference of $15 \mathrm{~A} / \mathrm{m}^{2}$. The samples were collected after 20 min of time interval and their COD was determined. In this study, the primary aim was to comprehend the effect of current density on COD i.e. COD removal profile was obtained for different combination of applied current density. Thus, results of performance of EC process for various combinations of applied current density have been reported as COD removal efficiency. The experiments were continued till the COD of effluent for three consecutive samples were almost same. This state was taken as steady state.

\subsubsection{COD result analysis}

After first reactor from the Fig. 3 it is clearly evident that COD removal efficiency increased from 37.69 to $75.95 \%$ as the current density was increased from 30 to $165 \mathrm{~A} / \mathrm{m}^{2}$. It was found that COD removal efficiency from current density 30 to $90 \mathrm{~A} / \mathrm{m}^{2}$ increased more rapidly i.e. from 37.69 to $71.56 \%$ as compared to current density 90 to $120 \mathrm{~A} / \mathrm{m}^{2}$ i.e. from 71.56 to $74.14 \%$. With further increase in current density from 135 to $165 \mathrm{~A} / \mathrm{m}^{2}$, removal efficiency increased from 74.89 to $75.95 \%$ i.e. only $1.06 \%$ thus can be considered as at steady state. It can also be concluded that as the current density increases there is reduction in results of COD as reported by earlier studies [24]. Maximum COD removal $(75.95 \%)$ after first reactor was found at current density $165 \mathrm{~A} / \mathrm{m}^{2}$.

After second reactor from the Fig. 4 , it is clearly evident that COD removal efficiency continuously increased from 59.03 to $90.18 \%$ with the increase in current density from 30 to $165 \mathrm{~A} / \mathrm{m}^{2}$, same trend as was observed in the case of the first reactor. Removal efficiency increased from 59.03 to $85.73 \%$ for an increase in current density for 30 to 120 $\mathrm{A} / \mathrm{m}^{2}$ because at a high current density, the level of anodic dissolution of aluminum increases, resulting in formation of greater amount of precipitate and removal of organics. And as we move to current density of 135 to $150 \mathrm{~A} / \mathrm{m}^{2}$ the increment in efficiency goes steady with the increase of $1.35 \%$. Maximum COD removal was obtained at current density $165 \mathrm{~A} / \mathrm{m}^{2}$ (90.18\%).
Fig. 3 COD removal efficiency after first reactor for current density 30 to $165 \mathrm{~A} / \mathrm{m}^{2}$

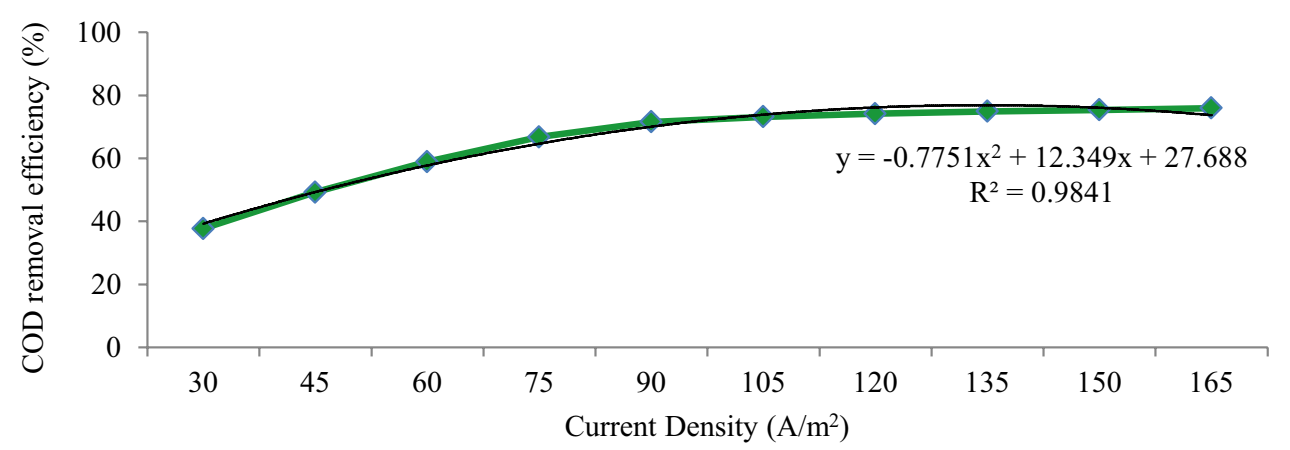


After settler from the Fig. 5 , it is clearly evident that COD removal increased constantly with an increase in the current density and reached maximum of $92.60 \%$ removal after settler for current density of $165 \mathrm{~A} / \mathrm{m}^{2}$.

Figure 6 represents the combined results of $C O D$ removal efficiency after first, second reactor and after settler for current density varied from 30 to $165 \mathrm{~A} / \mathrm{m}^{2}$, although, maximum removal reached $75.95 \%$ for first reactor at $165 \mathrm{~A} / \mathrm{m}^{2}$. There was much difference in COD removal efficiency after first reactor and settler from current density 30 to $135 \mathrm{~A} / \mathrm{m}^{2}$ but almost equal or little more increase in COD removal after second reactor and settler. In a similar study [35] it was observed that COD removal was $52.3 \%$ at a current density of $100 \mathrm{~A} / \mathrm{m}^{2}$ and
$76.1 \%$ at a current density of $200 \mathrm{~A} / \mathrm{m}^{2}$ at a constant flow rate of $10 \mathrm{~L} / \mathrm{h}$ and COD removal was $69.5 \%$ at $100 \mathrm{~A} / \mathrm{m}^{2}$ and $49.7 \%$ at $200 \mathrm{~A} / \mathrm{m}^{2}$.

The removal of COD concentration from its initial value to three different treatments (after 1 st reactor, after 2 nd reactor and settler) groups is summarized in Table 1. The initial (pre treatment) (mean \pm SD) COD was $514.00 \pm 0.00 \mathrm{mg} / \mathrm{L}$, after 20 min of treatments; it remained $175.94 \pm 67.41 \mathrm{mg} / \mathrm{L}$ after $1 \mathrm{st}$ reactor, $111.46 \pm 57.36 \mathrm{mg} / \mathrm{L}$ after 2 nd reactor and $97.88 \pm 54.91 \mathrm{mg} / \mathrm{L}$ after settler.

From initial, the mean COD removal was cumulatively $65.8,78.3$ and $81.0 \%$ at 1 st reactor, 2 nd reactor and settler respectively as shown in Fig. 7. In other words, the
Fig. 4 COD removal efficiency after second reactor for current density 30 to $165 \mathrm{~A} / \mathrm{m}^{2}$

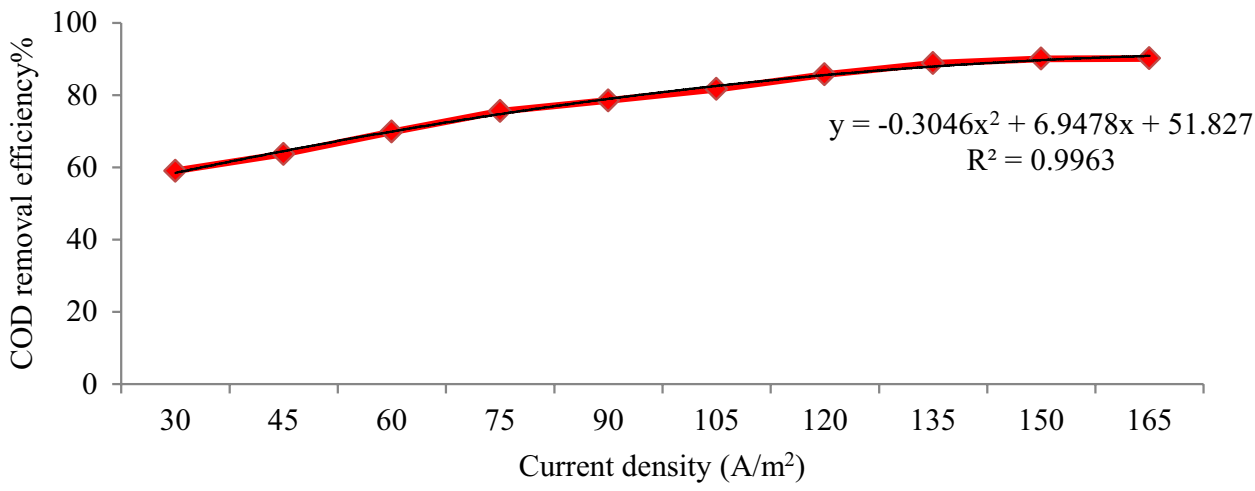

Fig. 5 COD removal efficiency after settler for current density 30 to $165 \mathrm{~A} / \mathrm{m}^{2}$

Fig. 6 COD removal efficiency after first, second reactor and after settler for current density 30 to $165 \mathrm{~A} / \mathrm{m}^{2}$
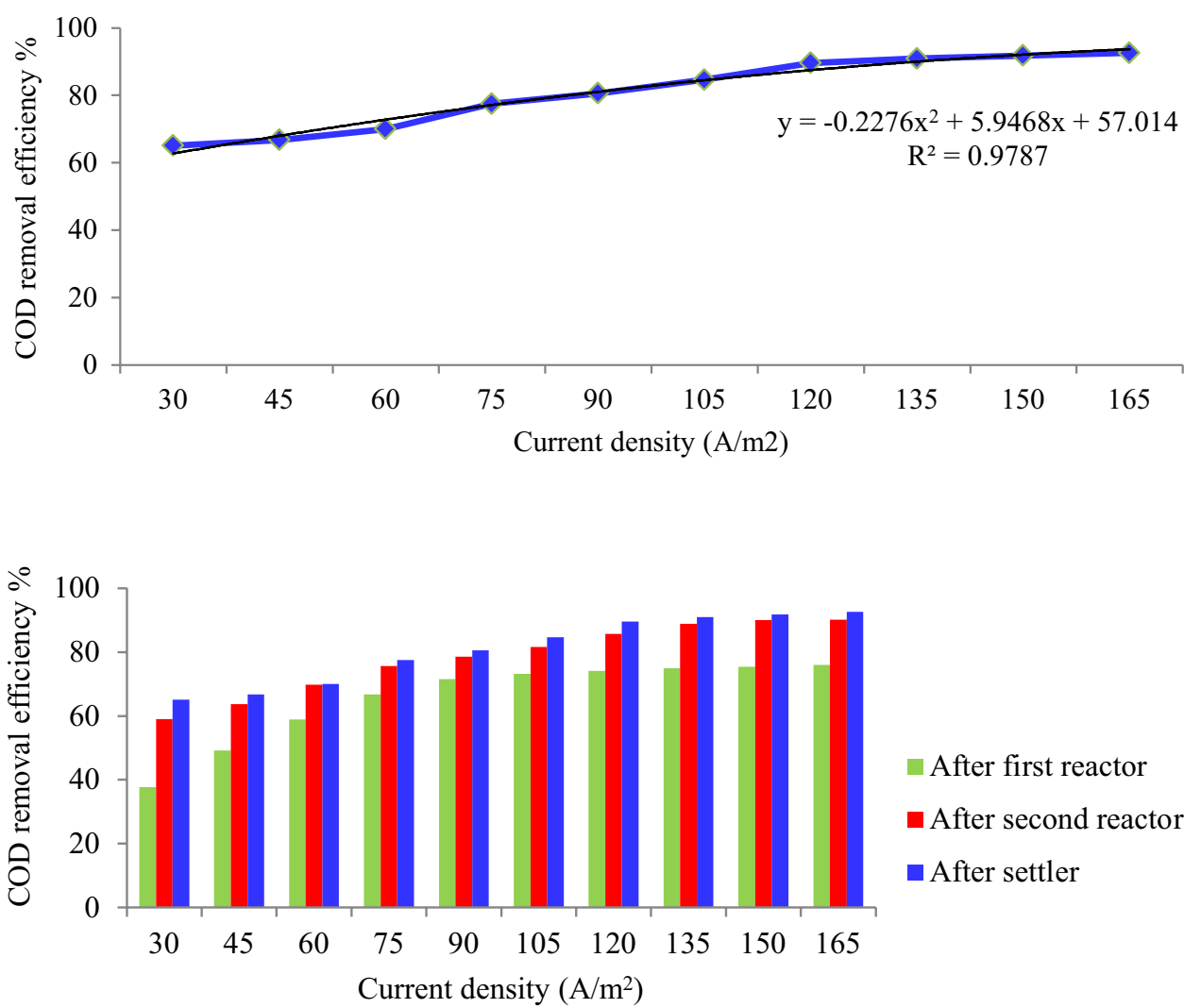
Table 1 Removal of COD concentration (mg/L) at three different processes

\begin{tabular}{lccc}
\hline Initial & After 1st reactor & After 2nd reactor & After settler \\
\hline $514.00 \pm 0.00$ & $175.94 \pm 67.41$ & $111.46 \pm 57.36$ & $97.88 \pm 54.91$ \\
\hline
\end{tabular}

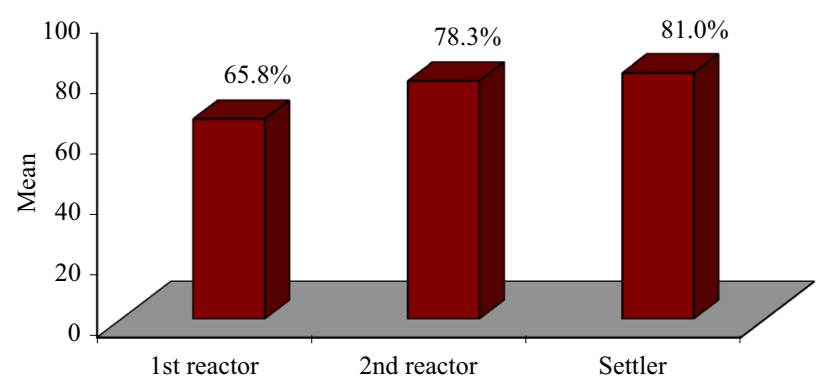

Fig. 7 Cumulative mean removal of COD concentration (\%) at three different processes

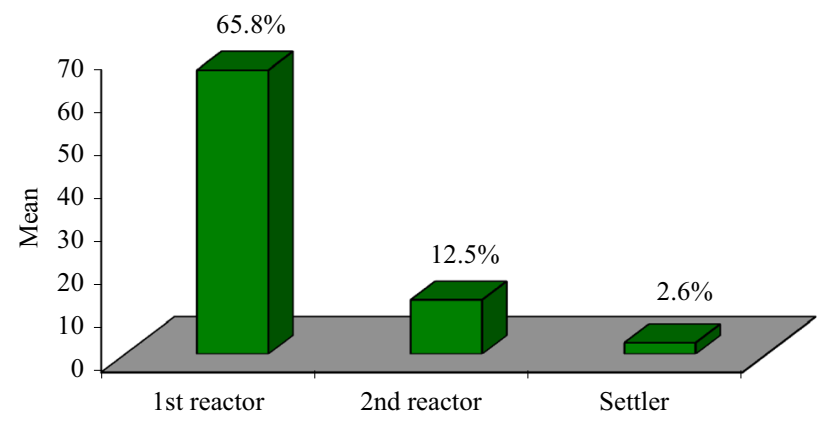

Fig. 8 Net mean removal of COD concentration (\%) at three different processes

mean COD removal was $65.8 \%$ at 1 st reactor, $12.5 \%$ at 2nd reactor and $2.6 \%$ at settler as shown in Fig. 8.

Comparing the pre (initial) and post (at 1st reactor, at 2nd reactor and settler) treatments COD of four groups together, ANOVA revealed significantly different $C O D$ among the groups $(F=141.30, P<0.001)$ as given in Table 2.

Further, after performing ANOVA, Tukey's HSD (honestly significant difference) post hoc test was done to compare the mean COD between the groups as given
Table 3 Comparison of COD concentrations between groups by Tukey's test

\begin{tabular}{lllll}
\hline Comparisons & Mean diff. & q & $P$ value & $95 \% \mathrm{Cl}$ of diff. \\
\hline $\begin{array}{l}\text { Initial versus 1st } \\
\text { reactor }\end{array}$ & 338.10 & 20.53 & $<0.001$ & $275.30-400.90$ \\
$\begin{array}{l}\text { Initial versus 2nd } \\
\text { reactor }\end{array}$ & 402.50 & 24.44 & $<0.001$ & $339.70-465.30$ \\
$\begin{array}{l}\text { Initial versus settler } \\
\text { nat }\end{array}$ & 416.10 & 25.27 & $<0.001$ & $353.30-478.90$ \\
\hline
\end{tabular}

in Table 3, Tukey's test showed significant $(P<0.001)$ removal of COD at 1 st reactor, 2 nd reactor and settler as compared to initial.

\subsection{Effect of current density on color removal}

The experiments were carried out to understand the effect of electrocoagulation process under continuous flow regime on various current densities varied from 30 to $165 \mathrm{~A} / \mathrm{m}^{2}$ in difference of $15 \mathrm{~A} / \mathrm{m}^{2}$. The samples were collected at regular time interval of $20 \mathrm{~min}$ and tested for $\%$ color removal. At various current densities, the results of performance of EC process have been reported as color removal efficiency.

\subsubsection{Color removal analysis}

Figure 9, clearly shows that as current density increases from 30 to $165 \mathrm{~A} / \mathrm{m}^{2}$, color removal efficiency increased from 52.46 to $81.92 \%$. This was due to the fact that with increasing current density, the amount of $\mathrm{Al}^{3+}$ cations released by the anode and therefore of $\mathrm{Al}(\mathrm{OH})_{3}$ particles also increases. From current density 30 to $120 \mathrm{~A} / \mathrm{m}^{2}$, color removal efficiency increases from 52.46 to $76.77 \%$ i.e. $24.31 \%$. Further increase in current density from 120 to $165 \mathrm{~A} / \mathrm{m}^{2}$, the rate of color removal efficiency slowed down and almost became same. Zheng et al. [34] also studied electrochemical treatment process for the treatment of wastewater and found a similar trend. At current density of $165 \mathrm{~A} / \mathrm{m}^{2}$, the maximum removal efficiency increases to $81.92 \%$, because at higher current density, the amount of anodic dissolution of aluminum increases, resulting in a superior amount of precipitate and removal of organics.
Table 2 Comparison of COD concentrations among groups using one way analysis of variance

\begin{tabular}{lrcccc}
\hline $\begin{array}{l}\text { Source of varia- } \\
\text { tion (SV) }\end{array}$ & Sum of square (SS) & $\begin{array}{l}\text { Degree of } \\
\text { freedom }(D F)\end{array}$ & Mean square (MS) & F ratio & $P$ value \\
\hline Groups & $1,150,000$ & 3 & 383,300 & 141.30 & $P<0.001$ \\
Residual & 97,650 & 36 & 2713 & & \\
Total & $1,247,000$ & 39 & 386,013 & & \\
\hline
\end{tabular}


After second reactor from the Fig. 10, it can be clearly observed that increase in current density from 30 to $165 \mathrm{~A} / \mathrm{m}^{2}$, color removal efficiency after second reactor increases from 61.79 to $90.40 \%$. From current density 30 to $105 \mathrm{~A} / \mathrm{m}^{2}$ removal efficiency rapidly increases from 61.79 to $82.08 \%$ i.e. $20.29 \%$. From current density 135 to 165 $\mathrm{A} / \mathrm{m}^{2}$ efficiency gradually increases and is almost same.

After settler it was observed that color removal showed a direct relationship with the current density reaching from $65.51 \%$ at $30 \mathrm{~A} / \mathrm{m}^{2}$ to a maximum of $93.11 \%$ at 165 $\mathrm{A} / \mathrm{m}^{2}$, as shown in Fig. 11 .

Figure 12 represents the combined results of color removal efficiency after first, second reactor and after settler for current density 30 to $165 \mathrm{~A} / \mathrm{m}^{2}$. In the similar study [35] observed that color removal for DR81 dye was $71.5 \%$ at a current density of $100 \mathrm{~A} / \mathrm{m}^{2}$ and $90.2 \%$ at a current density of $200 \mathrm{~A} / \mathrm{m}^{2}$ and a constant flow rate of $10 \mathrm{~L} / \mathrm{h}$. Also color removal was $61.5 \%$ at a current density
Fig. 9 Color removal efficiency after first reactor for current density 30 to $165 \mathrm{~A} / \mathrm{m}^{2}$
Fig. 10 Color removal efficiency after second reactor for current density 30 to $165 \mathrm{~A} / \mathrm{m}^{2}$

Fig. 11 Color removal efficiency after settler for current density 30 to $165 \mathrm{~A} / \mathrm{m}^{2}$
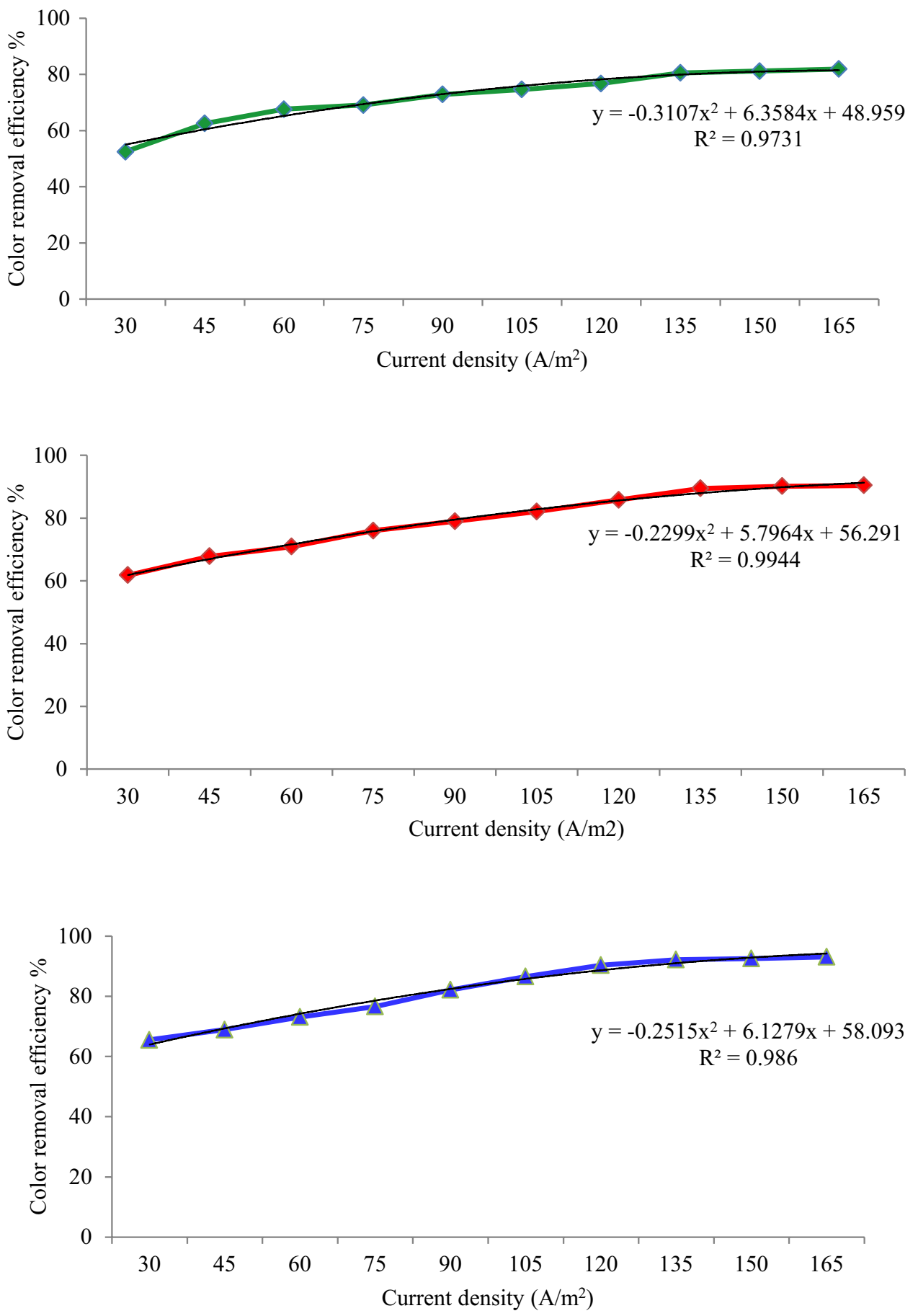

SN Applied Sciences 
Fig. 12 Color removal efficiency after first, second reactor and after settler for current density 30 to $165 \mathrm{~A} / \mathrm{m}^{2}$

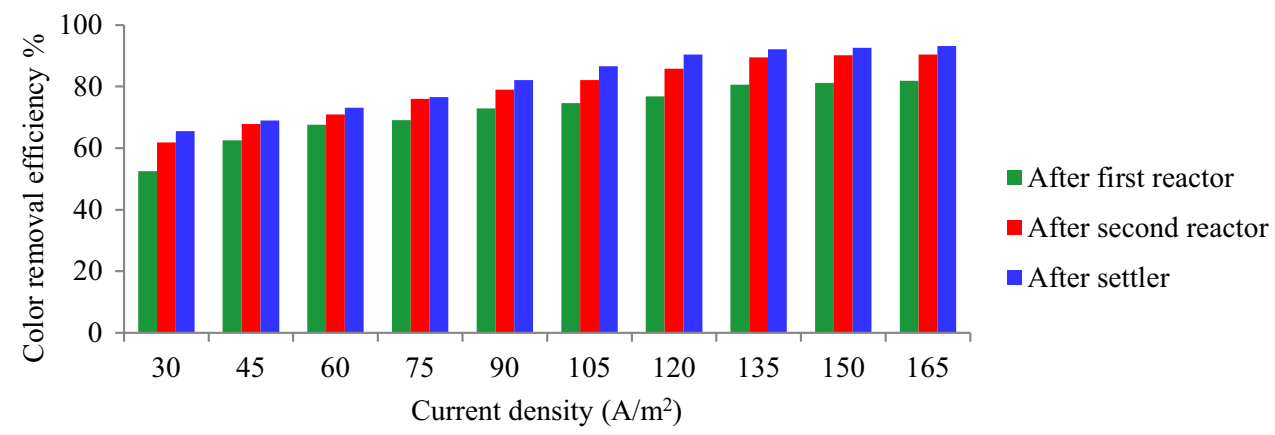

Table 4 Removal of color $(\mathrm{mg} / \mathrm{L})$ at three different processes

\begin{tabular}{llll}
\hline Initial & At 1st reactor & At 2nd reactor & Settler \\
\hline $300.00 \pm 0.00$ & $84.10 \pm 28.02$ & $62.04 \pm 30.23$ & $53.66 \pm 31.29$ \\
\hline
\end{tabular}

of $100 \mathrm{~A} / \mathrm{m}^{2}$ and $76.8 \%$ at a current density of $200 \mathrm{~A} / \mathrm{m}^{2}$ at a constant flow rate of $28 \mathrm{~L} / \mathrm{h}$. As $93.11 \%$ efficiency at high current density of $165 \mathrm{~A} / \mathrm{m}^{2}$ is insignificant as [13] predicted that as current density increases energy consumption in process will increase thus cost of the treatment of textile wastewater also increases. So from economic point of view, most suitable current density for process is $135 \mathrm{~A} / \mathrm{m}^{2}$ in term of COD and color removal efficiency giving removal of 90.93 and $92.18 \%$ respectively.

The removal of color from its initial to three different treatments (after 1st reactor, after 2 nd reactor and settler) groups is summarized in Table 4. The initial (pre treatment) mean $\pm S D$ color concentration was $300.00 \pm 0.00 \mathrm{mg} / \mathrm{L}$, after 20 min of treatments; it remained $84.10 \pm 28.02 \mathrm{mg} / \mathrm{L}$ after 1 st reactor, $62.04 \pm 30.23 \mathrm{mg} / \mathrm{L}$ after 2 nd reactor and $53.66 \pm 31.29 \mathrm{mg} / \mathrm{L}$ after settler.

From initial, the mean color concentration removed cumulatively was $72.0,79.3$ and $82.1 \%$ at 1 st reactor, 2 nd reactor and settler respectively (Fig. 13). In other words, the mean color removed was $65.8 \%$ at 1 st reactor, $7.4 \%$ at 2nd reactor and 2.8\% at settler as shown in Fig. 14.

Comparing the pre (initial) and post treatments (at 1st reactor, at 2nd reactor and settler) color concentration of four groups together, ANOVA revealed significantly different color concentration among the groups $(F=205.90$, $P<0.001)$ as given in Table 5.

Further, after performing ANOVA, Tukey's HSD (honestly significant difference) post hoc test is done to compare the mean color concentration between the groups as given in Table 6, Tukey's test showed significant $(P<0.001)$ removal of color after 1 st reactor, 2 nd reactor and settler as compared to initial mean concentration.

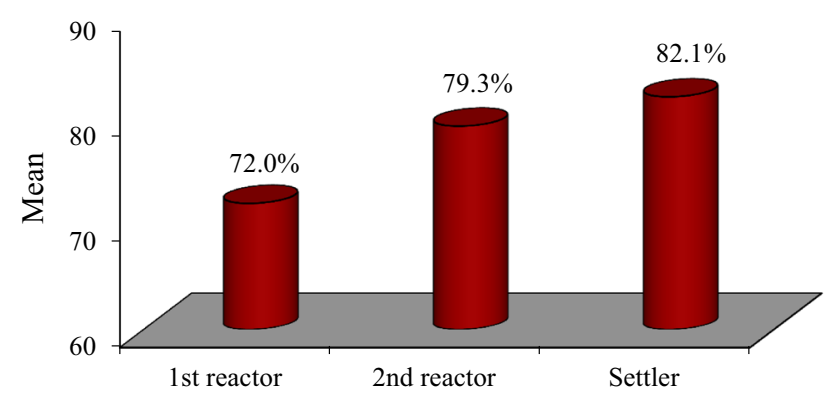

Fig. 13 Cumulative mean removal of color (\%) at three different processes

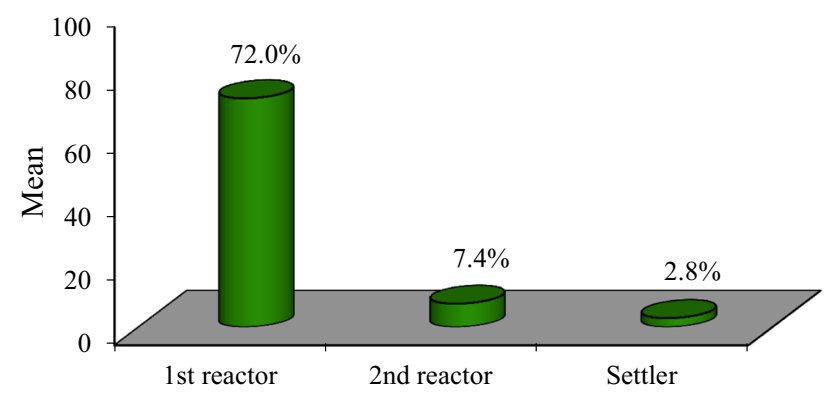

Fig. 14 Net mean removal of color (\%) at three different processes

Table 5 Comparison of color concentration among groups using one way analysis of variance

\begin{tabular}{lrrrrr}
\hline $\begin{array}{l}\text { Source of vari- } \\
\text { ation (SV) }\end{array}$ & SS & \multicolumn{1}{l}{ MS } & F value & $P$ value \\
\hline Groups & 413,500 & 3 & 137,800 & 205.90 & $<0.001$ \\
Residual & 24,100 & 36 & 670 & & \\
Total & 437,600 & 39 & 138,470 & & \\
\hline
\end{tabular}


Table 6 Comparison of color concentration between groups by Tukey's test

\begin{tabular}{lllll}
\hline Comparison & Mean diff. & q & $P$ value & $95 \% \mathrm{Cl}$ of diff. \\
\hline $\begin{array}{l}\text { Initial versus 1st } \\
\text { reactor }\end{array}$ & 215.90 & 26.39 & $<0.001$ & $184.70-247.10$ \\
$\begin{array}{l}\text { Initial versus 2nd } \\
\text { reactor }\end{array}$ & 238.00 & 29.08 & $<0.001$ & $206.80-269.20$ \\
\begin{tabular}{l} 
Initial versus settler \\
\hline
\end{tabular} & 246.30 & 30.11 & $<0.001$ & $215.10-277.50$ \\
\hline
\end{tabular}

\subsection{Effect of current density on electrode consumption}

Electrode consumption (weight loss) during the 1st reactor and 2nd reactor process is summarized in Tables 7 and 8 respectively. The initial (pre treatment) mean weight of electrode at 1 st reactor was $44,965.70 \pm 490.07 \mathrm{mg}$ and after $20 \mathrm{~min}$ of process it was $44,803.63 \pm 537.40 \mathrm{mg}$. Comparing the pre and post electrode weight, $t$ test reveled significant electrode consumption $(162.07 \pm 51.84 \mathrm{mg}$ or $0.36 \%)$ at post as compared to pre $(44,965.70 \pm 490.07$ vs. $44,803.63 \pm 537.40, \mathrm{t}=9.89, P<0.001)$. Hakizimana et al. [9] also found the similar trend for electrode consumption as was achieved in the present study.

Similarly, the initial (pre treatment) mean weight of electrode at 2 nd reactor was $45,447.59 \pm 75.15 \mathrm{mg}$ and after $20 \mathrm{~min}$ of process it was $45,419.56 \pm 80.64 \mathrm{mg}$. Comparing the pre and post electrode weight, $t$ test reveled significant electrode consumption $(28.03 \pm 8.92 \mathrm{mg}$ or $0.06 \%)$ at post as compared to pre $(45,447.59 \pm 75.15$ vs. $45,419.56 \pm 80.64, \mathrm{t}=9.94, P<0.001)$.

Further, correlating the removal of COD concentration and electrode weight loss of both the processes (1st reactor and 2nd reactor), Pearson correlation analysis revealed a significant and positive correlation between COD removal and electrode weight loss $(r=0.98, P<0.001)$ indicating as removal of COD concentration increases electrode weight loss increases as shown in Fig. 15.

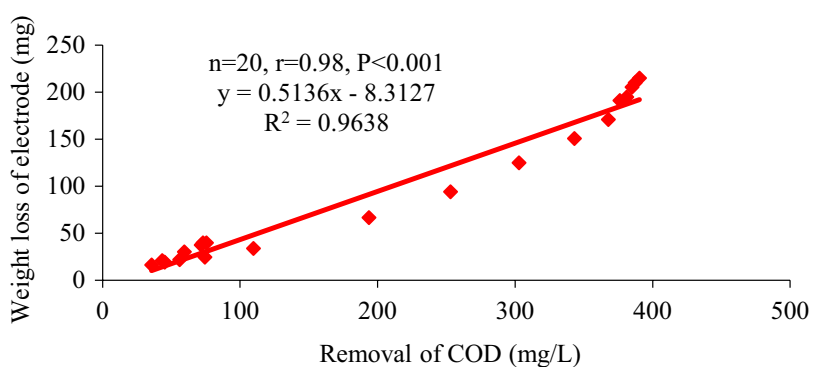

Fig. 15 Correlation between removal of COD concentration (mg/L) and electrode consumption (mg)

\section{Conclusions}

The result observed in this work shows the application of electrocoagulation process in the treatment of wastewater being discharged from different textile industries. In treating the wastewater for COD and color the efficiency level increases with increase in current density but the rate of increase decline with increasing current density above a certain value. It can be concluded that for highest level of current density the COD and color removal reached a maximum of 92.60 and $93.11 \%$ respectively, however more electrode was consumed during the process. For COD removal and color removal, most significant current density in double stage electrocoagulation with settler was $135 \mathrm{~A} / \mathrm{m}^{2}$ in which COD and color removal was 90.93 and $92.18 \%$ respectively. In case of electrode consumption it was also observed that the consumption of electrode was less in second reactor as compared to first reactor on increase of current density giving improved efficiency of COD. Statistically, we concluded from the study that in case of COD on comparing the results of four groups which comprises of initial concentration and results after first reactor, second reactor and settler, ANOVA revealed significantly different COD concentrations among the groups. Further, comparing the mean COD between the groups, Tukey's test showed significant $(P<0.001)$ removal of $C O D$ at 1 st reactor, 2 nd reactor and settler as compared to initial. In case of color on comparing the results of four
Table 7 Electrode consumption $(\mathrm{mg})$ at $1 \mathrm{st}$ reactor

\begin{tabular}{lllll}
\hline Initial & Final & $\begin{array}{l}\text { Weight loss (initial- } \\
\text { final) }\end{array}$ & t value $(D F=9)$ & $P$ value \\
\hline $44,965.70 \pm 490.07$ & $44,803.63 \pm 537.40$ & $162.07 \pm 51.84$ & 9.89 & $<0.001$ \\
\hline
\end{tabular}

Table 8 Electrode consumption (mg) at 2 nd reactor

\begin{tabular}{lllll}
\hline Initial weight $(\mathrm{mg})$ & Final weight $(\mathrm{mg})$ & $\begin{array}{l}\text { Weight loss (initial- } \\
\text { final) }\end{array}$ & t value $(D F=9)$ & $P$ value \\
\hline $45,447.59 \pm 75.15$ & $45,419.56 \pm 80.64$ & $28.03 \pm 8.92$ & 9.94 & $<0.001$ \\
\hline
\end{tabular}


groups together, ANOVA revealed significantly different color concentration among the groups. Further, comparing the mean color concentration between the groups, Tukey's test showed significant $(P<0.001)$ removal of color at 1 st reactor, 2 nd reactor and settler as compared to initial. In case of electrode consumption, comparing the pre and post electrode weight, $t$ test revealed significant electrode consumption. Further correlating the removal of COD concentration $(\mathrm{mg} / \mathrm{L})$ and electrode weight loss (mg) by Pearson correlation analysis for both processes (1st reactor and 2 nd reactor) a significant and positive correlation between COD removal and electrode weight loss $(r=0.98, P<0.001)$ was observed, indicating that as removal of COD concentration increases, electrode weight loss also increases.

Acknowledgements The first author expresses their thankfulness to the Director IET Lucknow for providing necessary support to carry out this research work. This study was funded by TEQIP-II (Grant Number 2013/08/03).

\section{Compliance with ethical standards}

Conflict of interest There is no conflict of interest.

\section{References}

1. Bayramoglu M, Eyvaz M, Kobya M (2007) Treatment of the textile wastewater by electrocoagulation: economic evaluation. Chem Eng J 128:155-161

2. Bhatnagar R, Joshi H, Mall ID, Srivastava VC (2014) Electrochemical oxidation of textile industry wastewater by graphite electrodes. J Environ Sci Health Part A 49(8):955-966

3. Camcioglu S, Ozyurt B, Hapoglu H (2017) Effect of process control on optimization of pulp and paper mill wastewater treatment by electrocoagulation. Process Saf Environ Prot 111:300-319

4. Can OT, Kobya M, Demirbas E, Bayramoglu M (2006) Treatment of the textile wastewater by combined electrocoagulation. Chemosphere 62:181-187

5. Dhiman N, Markandeya, Singh A, Verma NK, Ajaria N, Patnaik S (2017) Statistical optimization and artificial neural network modeling for acridine orange dye degradation using in situ synthesized polymer capped $\mathrm{ZnO}$ nanoparticles. J Colloid Interface Sci 493:295-306

6. Emamjomeh MS (2009) Review of pollutants removed by electrocoagulation. J Environ Manag 90:1663-1679

7. Ghadim AA (2013) Optimization of electrocoagulation process for removal of an azo dye using response surface methodology and investigation on the occurence of destructive side reactions. Chem Eng Process Process Intensif 64:68-78

8. Gunukula S (2011) Electrocoagulation/floatation treatment of synthetic surface water. Cleverland State University, Cleverland

9. Hakizimana JN, Gourich B, Chafi M, Stiriba Y, Vial C, Drogui P, Naja J (2017) Electrocoagulation process in water treatment: a review of electrocoagulation modeling approaches. Desalination 404:1-21
10. Hansen HN (2007) Electrocoagulation in wastewater containing arsenic: comparing different designs. Electrochem Acta 52:3464-3470

11. Haq I, Raj A, Markandeya (2018) Biodegradation of Azure-B dye by Serratia liquefaciens and its validation by phytotoxicity, genotoxicity and cytotoxicity studies. Chemosphere 196:58-68

12. Kisku GC, Markandeya, Shukla SP, Singh DS, Murthy RC (2015) Characterization and adsorptive capacity of coal fly ash from aqueous solutions of disperse blue and disperse orange dyes. Environ Earth Sci 74(2):1125-1135

13. Kobya M, Can OT, Bayramoglu M (2003) Treatment of textile wastewaters by electrocoagulation using iron and aluminum electrodes. J Hazard Mater 100:163-176

14. Markandeya, Shukla SP, Kisku GC (2015) Linear and non-linear kinetic modeling for the adsorption of disperse dye in a batch process. Res J Environ Toxicol 9(6):320-331

15. Markandeya, Singh A, Shukla SP, Mohan D, Singh NB, Bhargava DS, Shukla R, Pandey G, Yadav VP, Kisku GC (2015) Adsorptive capacity of sawdust for the adsorption of $\mathrm{MB}$ dye and designing of two-stage batch adsorber. Cogent Environ Sci 1(1):1075856

16. Markandeya, Dhiman N, Shukla SP, Kisku GC (2017) Statistical optimization of process parameters for removal of dyes from wastewater on chitosan cenospheres nanocomposite using response surface methodology. J Clean Product 149:597-606

17. Markandeya, Shukla SP, Dhiman N (2017) Characterization and adsorption of disperse dyes from wastewater onto cenospheres activated carbon composites. Environ Earth Sci 76:702-714

18. Markandeya, Shukla SP, Dhiman N, Mohan D, Kisku GC, Roy S (2017) An efficient removal of disperse dye from wastewater using zeolite synthesized from cenospheres. J Hazard Toxic Radioact Waste 21(4):04017017

19. Markandeya, Shukla SP, Mohan D (2017) Toxicity of disperse dyes and its removal from wastewater using various adsorbents: a review. Res J Environ Toxicol 9:01-18

20. Markandeya, Dhiman N, Shukla SP, Mohan D, Kisku GC, Patnaik S (2018) Comprehensive remediation study of disperse dyes containing wastewater by using environmental benign, low cost cenospheres nanosyntactic foam. J Clean Product 182:206-216

21. Martinez-Huitle CB (2009) Decontamination of wastewaters containing synthetic organic dyes by electro chemical methods. Appl Catal B87:105-145

22. Mouedhen GF (2008) Behavior of aluminum electrodes in electrocoagulation process. J Hazard Mater 150:124-135

23. Ojha A, Markandeya (2016) Lignin decolorization and degradation of pulp and paper mill effluent by Ligninolytic Bacteria. Iran J Energy Environ 7(3):282-291

24. Pajootan E, Arami M, Mahmoodi NM (2012) Binary system dye removal by electrocoagulation from synthetic and real colored wastewaters. J Taiwan Inst Chem Eng 43(2):282-290

25. Pandey SS, Singh NB, Shukla SP, Markandeya (2017) Removal of lead and copper from textile wastewater using egg shells. Iran J Energy Environ 8(3):202-209

26. Parshetti G, Kalme S, Saratale G, Gowindwar S (2006) Biodegradation of malachite green by Kocuria rosea MTCC 1532. Acta Chim Slov 53(4):492-498

27. Shukla SP, Singh A, Dwivedi L, Sharma KJ, Bhargava DS, Shukla R, Singh NB, Yadav VP, Markandeya (2014) Minimization of contact time for two-stage batch adsorber design using second-order kinetic model for adsorption of methylene blue (MB) on used tea leaves. Int J Sci Innov Res 2(1):58-66

28. Shukla SP, Tiwari S, Tiwari M, Mohan D, Pandey G (2017) Removal of fluoride from aqueous solution using Psidium guajava leaves. Desalination Water Treat 62:418-425

29. Singh NB, Srivastava YK, Shukla SP, Markandeya (2019) Investigating the efficacy of saw dust in fluoride removal through 
adsorption. J Inst Eng (India) Ser A 1:1. https://doi.org/10.1007/ s40030-019-00387-7

30. Siringi DH (2012) Is electrocoagulation a solution to the treatment of wastewater and providing clean water for daily use. ARPN J Eng Appl Sci 7:2

31. Standards Methods for Examination of Water and Wastewater (2012) American Public Health Association, American Water Work Association and Water Pollution Control Federation, 22nd, Washington, DC

32. Tiwari M, Shukla SP, Bhargava DS, Kisku GC (2013) Color removal potential of coal fly ash-a low cost adsorbent from aqueous solutions of disperse dyes used in textile mill through batch techniques. Our Earth 10(4):05-07
33. Tiwari M, Shukla SP, Mohan D, Bhargava DS, Kisku GC (2015) Modified cenospheres as an adsorbent for the removal of disperse dyes. Adv Environ Chem 2015:1-8

34. Zheng T, Wang J, Wang Q, Meng H, Wang L (2017) Research trends in electrochemical technology for water and wastewater treatment. Appl Water Sci 7(1):13-30

35. Zodi SM (2013) Direct red 81 dye removal by a continuous flow electrocoagulation/floatation reactor. Sep Purif Technol J 108:215-222

Publisher's Note Springer Nature remains neutral with regard to jurisdictional claims in published maps and institutional affiliations. 